\title{
A vanishing raptor in a Mediterranean island: an updated picture of Red kite (Milvus milvus) in Sardinia, Italy
}

\author{
Davide De Rosa ${ }^{1 *}$, Ilaria Fozzi ${ }^{1,2}$, Alberto Fozzi ${ }^{3}$, Mauro Sanna ${ }^{4}$, \\ Jan Škrábal ${ }^{5}$, Rainer Raab ${ }^{6}$, Benedetta Catitti ${ }^{7}$, Andrea Rotta ${ }^{8}$, Ivan Literák ${ }^{5}$, \\ Fiammetta Berlinguer ${ }^{9}$, Mauro Aresu ${ }^{10}$
}

\begin{abstract}
In the $19^{\text {th }}$ century, Red kite (Milvus milvus) was very common and widespread in Sardinia, but in the mid-900 an important decline occurred. Since the 1970s the species has been studied more continuously, but in recent years the published data seem contradictory. In 2018-2020, authors carried out specific research to collect data on the population of the Red kite in Sardinia exploring both the historical range of the species and areas where the species was reported in the past. In 2018-2020, we estimated 10-13 breeding pairs in an area of about $3,440 \mathrm{~km}^{2}$ located in the north west of Sardinia. As regard wintering, we estimated 30-40 birds in winters 2018-2019 and 2019-2020, whereas 90-110 birds were counted in winter 2020-2021.
\end{abstract}

Key words: Milvus milvus, Sardinia, breeding, wintering, migration, GPS telemetry, raptors.

Riassunto - Un rapace in declino in un'isola del Mediterraneo: un quadro aggiornato del nibbio reale (Milvus milvus) in Sardegna, Italia.

${ }^{1}$ ARDEA - Associazione per la Ricerca, la Divulgazione e l'Educazione Ambientale APS, Via Ventilabro 6, 80126 Napoli, Italia.

${ }^{2}$ Osservatorio Faunistico del Parco Nazionale dell'Asinara, Loc. Tumbarino, 07046 Porto Torres (SS), Italia.

${ }^{3}$ Regione Sardegna, Direzione Generale della Protezione Civile Ufficio territoriale di Olbia, Via Vena Fiorita 1, 07026 Olbia (SS), Italia.

${ }^{4}$ Via Baldedda 12, 07100 Sassari, Italia.

5 Department of Biology and Wildlife Diseases, Faculty of Veterinary Hygiene and Ecology, University of Veterinary and Pharmaceutical Sciences Brno, Palackého tř. 1, 61242 Brno, Czech Republic.

${ }^{6}$ Technisches Büro für Biologie, Quadenstrasse 13, 2232 DeutschWagram, Austria.

Swiss Ornithological Institute, Seerose 1, CH-6204 Sempach, Switzerland.

${ }^{8}$ Via Mentana 1, 07024 La Maddalena (SS), Italia.

${ }^{9}$ Università degli Studi di Sassari - Dipartimento di Medicina Veterinaria, Via Vienna 2, 07100 Sassari, Italia.

${ }^{10}$ Via Crispi 5, 08015 Macomer (NU), Italia.

* Corresponding author: derosadavide@yahoo.it

(C) 2021 Davide De Rosa, Ilaria Fozzi, Alberto Fozzi, Mauro Sanna, Jan Škrábal, Rainer Raab, Benedetta Catitti, Andrea Rotta, Ivan Literák, Fiammetta Berlinguer, Mauro Aresu

Received: 15 February 2021

Accepted for publication: 22 March 2021

Online publication: 16 April 2021
Nel diciannovesimo secolo il nibbio reale (Milvus milvus) era molto comune e diffuso in Sardegna, ma a metà del secolo si verificò un importante declino. Dagli anni ' 70 la specie è stata studiata con più continuità, ma negli ultimi anni i dati pubblicati sembrano contraddittori. Nel 2018-2020, gli autori hanno svolto ricerche specifiche per raccogliere dati sulla popolazione del nibbio reale in Sardegna esplorando sia l'attuale areale delle specie sia le aree in cui la specie è stata segnalata in passato. Nel 2018-2020 abbiamo stimato 10-13 coppie nidificanti in un'area di circa 3.440 $\mathrm{km}^{2}$ situata nel nord ovest della Sardegna. Per quanto riguarda lo svernamento, abbiamo stimato 30-40 uccelli negli inverni 2018-2019 e 2019-2020, mentre sono stati stimati 90-110 uccelli nell'inverno 2020-2021.

Parole chiave: Milvus milvus, Sardegna, popolazione, svernamento, migrazione, telemetria GPS, rapaci.

\section{INTRODUCTION}

The Red kite (Milvus milvus) is present in Annex I of Directive 2009/147/EEC and in Annex II of the Convention of Bonn on migratory species. It is also considered Near Threatened with a negative trend by IUCN (BirdLife International, 2019), Vulnerable in Italian Red List (Gustin et al., 2019) and Critically endangered in Sardinian Red list (Schenk, 2015).

The Red kite (Fig. 1) is a large migratory raptor, endemic to Western Europe, usually associated with open agricultural areas used for extensive and mixed farming, where land is mainly grass covered (David et al., 2017).

At present Milvus milvus breed in 24 European countries and the global breeding population consists of 32,000 to 38,000 pairs with more than $90 \%$ of the population concentrated in six countries (Germany, United Kingdom, Sweden, Switzerland, France and Spain) (Aebischer, 2018).

Populations in Spain, in the south of France, in Italy, on the Mediterranean islands and in the UK are largely resident, but elsewhere in the EU most of the populations move south and west to a varying extent, many of them wintering in Spain and Portugal (Knott et al., 2009).

The breeding population size in Italy has been assessed in 426-519 pairs with over $80 \%$ concentrated in Basilicata, Abruzzi and Molise. Small populations are also present in Calabria, Puglia, Lazio, Tuscany, Marche and Sardinia (Cillo \& Laterza, 2014). 


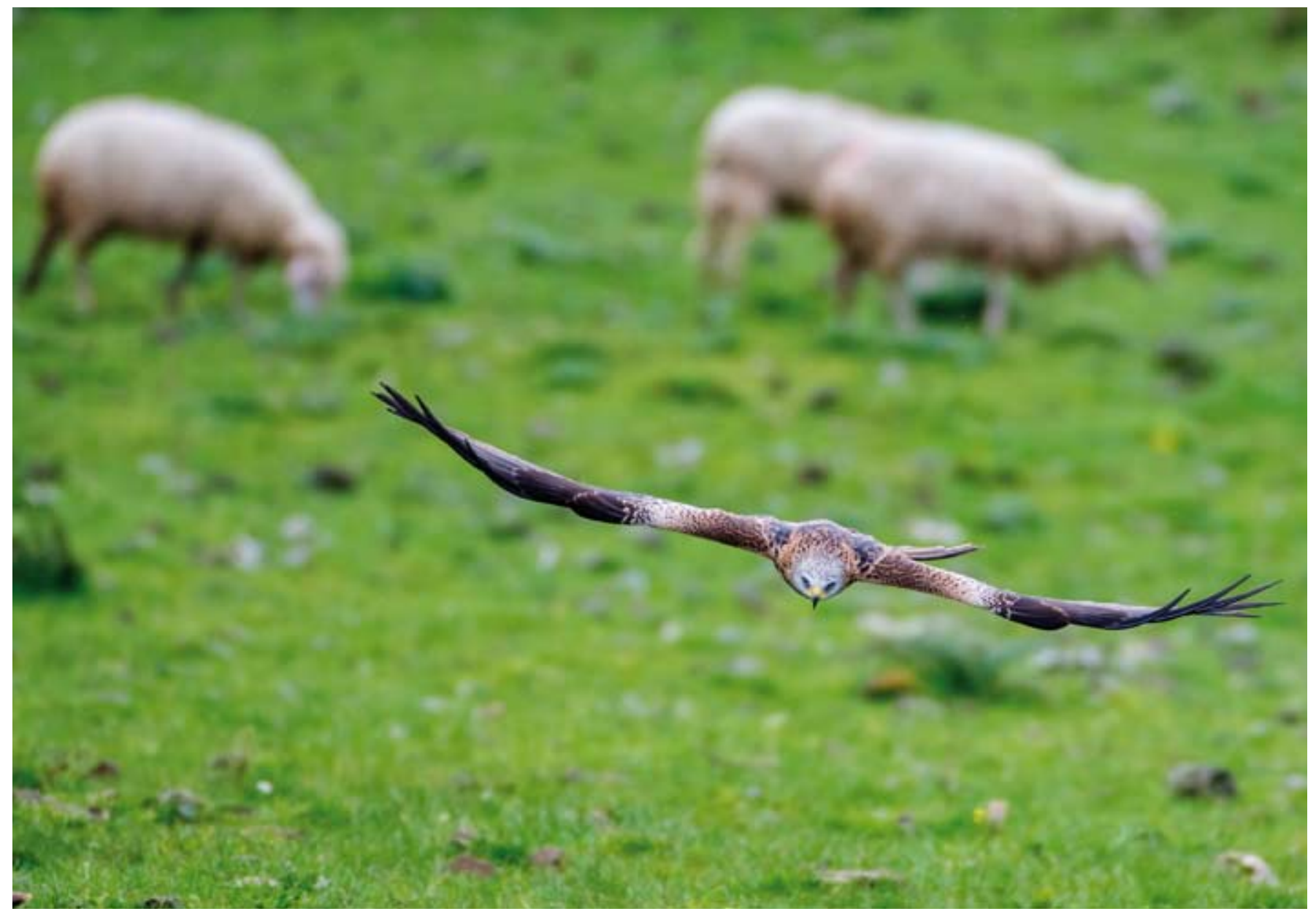

Fig. 1 - Red kite in Sardinia. / Nibbio reale in Sardegna. (Photo: / Foto: Mauro Sanna).

In the $19^{\text {th }}$ century, the species was very common and widespread in Sardinia (Salvatori, 1864; Brooke, 1873; Lepori, 1882), but in the mid-900 an important decline occurred as highlighted by Bezzel (1957).

Since the 1970s (Schenk, 1976) the species has been studied more continuously, but in recent years the published data seem contradictory (Grussu et al., 2012; Fulco et al., 2017). Therefore this study aims to clarify and give an updated picture of the breeding and wintering population of Red kite in Sardinia.

\section{METHODS}

In 2018-2020, authors carried out specific research to collect data on the population of the Red kite in Sardinia (Fig. 2). During the breeding period (February-July) we explored both the current known range and the historical one recording presence/absence data and, when it was possible with a minimal disturbance, the nest location. Regarding winter period (November-January), we looked for groups and roosts using the road transects technique (De Rosa et al., 2015) to investigate the current known range and the historical one, and we also looked for roosts and groups at the feeding points for Griffon vulture (Gyps fulvus) built within the LIFE Project Under Griffon Wings (Berlinguer, 2020).
In addition to this data, we used tracks of birds equipped with GPS tagged in mainland Europe to look for their positions in Sardinia and detect other individuals.

For the estimation of Red kite breeding home range, we used the minimum data (18 km from the nests) of the national ecological network data sheets (Boitani et al., 2002).

\section{RESULTS}

The numbers of estimated breeding pairs of Red kites are shown in (Table 1). Distribution of breeding pairs is visible in Figure 3 in an area of about $3,440 \mathrm{~km}^{2}$ located in the north west of Sardinia.

Four Natura 2000 sites (SCI ITB211101 Altopiano di Campeda; SCI ITB020041 Entroterra e zona costiera tra Bosa, Capo Marrargiu e Porto Tangone; SPA ITB023050 Piana di Semestene, Bonorva, Macomer e Bortigali; SPA ITB023037 Costa e Entroterra di Bosa, Suni e Montresta) are present in the breeding home range and represent only $14 \%$ of the area (Fig. 3). The area is characterized by grazing areas alternating with Mediterranean scrub areas and Holm or Cork oak woods. There are many extensive livestock farms, especially sheep, and small inhabited centres. 


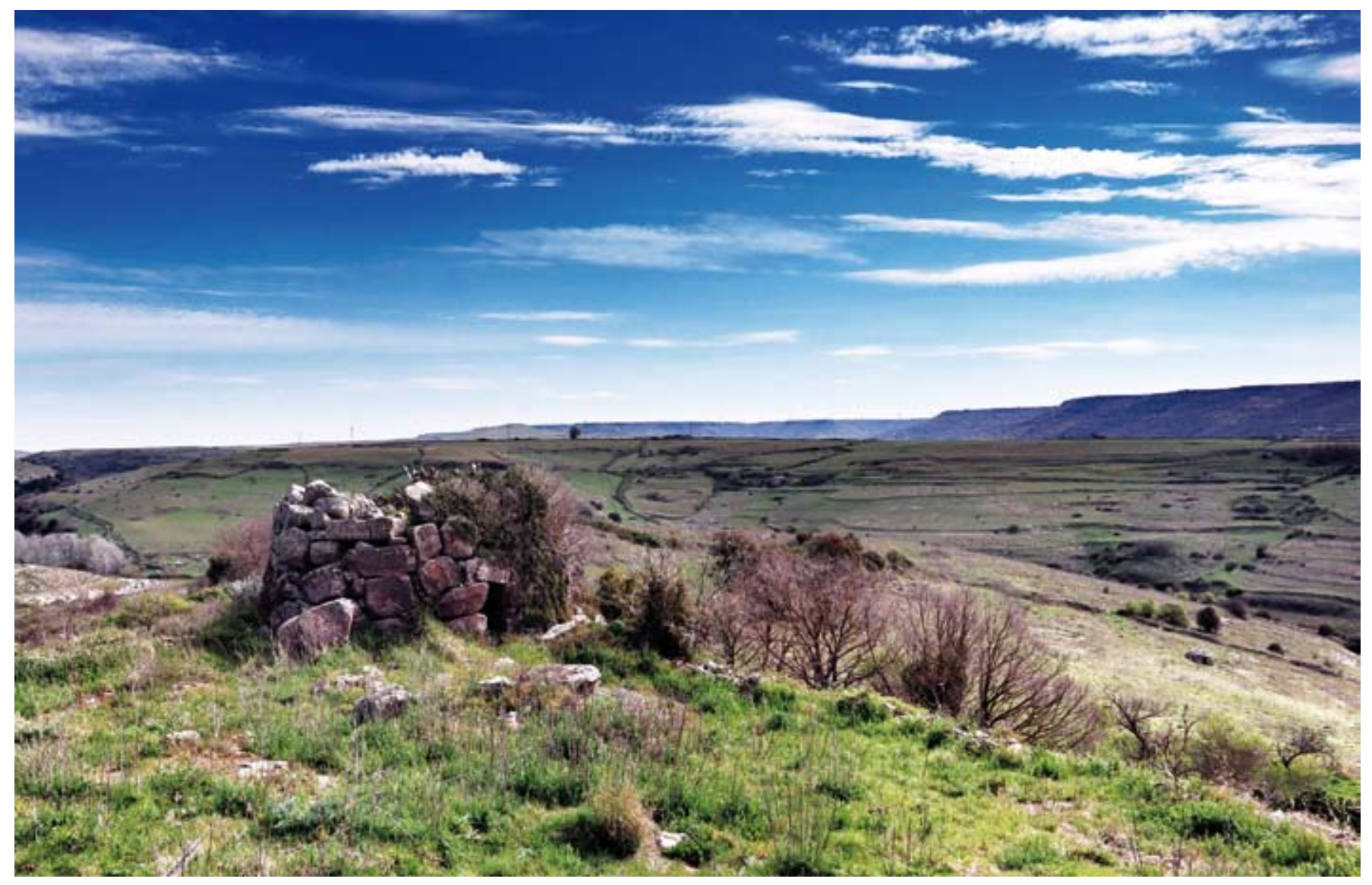

Fig. 2 - Red kite habitat in north west Sardinia. / Habitat del nibbio reale nel nordovest Sardegna. (Photo: / Foto: Uccio Saccu).

Tab. 1 - Red kite breeding pairs in Sardinia 1971-2020. / Coppie nidificanti di nibbio reale in Sardegna nel periodo1971-2020.

\begin{tabular}{|c|c|c|c|}
\hline Years & Breeding pairs & Trend & References \\
\hline $1971-1975$ & $20-30$ & & Schenk 1976 \\
\hline 1981 & $10-20$ & Decreasing & Massa \& Schenk 1983 \\
\hline $1990-1993$ & $8-15$ & Decreasing & Schenk 1995 \\
\hline $1990-1995$ & $10-15$ & Stable & Grussu 1995 \\
\hline $2001-2005$ & $15-22$ & Increasing & Grussu et al. 2006 \\
\hline $2006-2011$ & $20-25$ & Increasing? & Grussu et al. 2012 \\
\hline $2018-2020$ & $10-13$ & Decreasing? & Present work \\
\hline
\end{tabular}

In Figure 4 an unpublished figure of 1985-1994 Red kite distribution is shown (Aresu M., Fozzi A., Marras G., Schenk H., pers. comm.).

Regarding winter, in these 3 years we explored the territory with road transects technique for $2,462.4 \mathrm{~km}$ looking for roosts, but in the 2018-2019 and 2019-2020 we didn't find any, we only observed pre-roost groups with a maximum of 6 birds. At the end of November 2020, we observed a pre-roost group of 21 birds that later split into two groups roosting about $1 \mathrm{~km}$ apart.

During other observations in 2018-2019 and 20192020 we saw adults present in pre-roost site that later abandoned the group probably to sleep near their nest.
At the end of December 2020, we observed a very high number of birds in a new roost site, 87 birds on December $23^{\text {rd }}$ (De Rosa et al., 2020). This high number probably is linked to a big snow in Corsica. Unfortunately, we were not able to follow the evolution of the roost because of the restriction due to the pandemic situation in Italy; then, on January $8^{\text {th }}, 2021$ we counted 51 Red kites including a young female with GPS coming from Switzerland.

The maximum group observed during 2018-2020 at the feeding point installed for Griffon Vulture was of 9 birds in the February 2020 in the core area of the home range (Padria - SS) and 12 birds at the end of November 2020 near Pozzomaggiore (SS). 


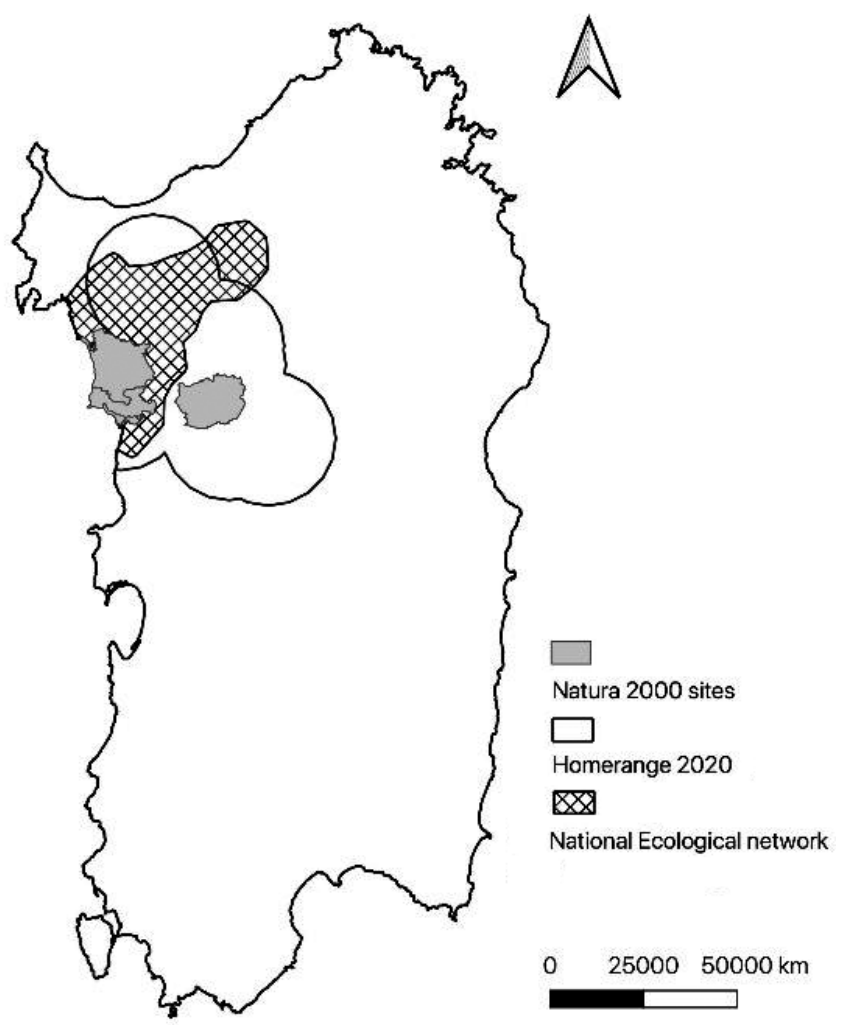

Fig. 3 - Red kite breeding distribution range in Sardinia 2018-2020. / Areale di nidificazione del nibbio reale in Sardegna nel periodo 20182020 .

During the winter it is also possible to see single birds in the north-east of the island and very rarely in the south of the island, such as in winter 2017-18 when a bird equipped with GPS coming from Czech Republic was observed with another juvenile near a dump in San Gavino Monreale (SU) and in 2020 when a bird equipped with GPS arrived from Switzerland flying all over Sardinia (Fig. 5). Another bird coming from Czech Republic arrived in Sardinia in 2014 but researchers lost its signal after two days near Teulada (SU) (Fig.5).

Thanks to all these data we estimated a wintering population of 30-40 birds in 2018-2019 and 2019-2020, and a wintering population of $90-110$ birds in 2020-2021.

\section{DISCUSSION}

The Red kite was considered common and resident in Sardinia until the end of the nineteenth century, but since the second half of the last century the species has experienced a progressive contraction of its habitat until the period 1990-1995 when its breeding population was 8-15 pairs (Schenk, 1995), concentrated in the northwest of the island. Comparing the current distribution with the historical one, the Red kite has completely disappeared as breeder from the east and south of the island.

In 2012 Grussu et al. estimate 20-25 pairs explaining that this increase depended to a more precise census of the population rather than a real recent increase.

Despite this value, the wintering population declared by in the immediately following period (2013-2017) was

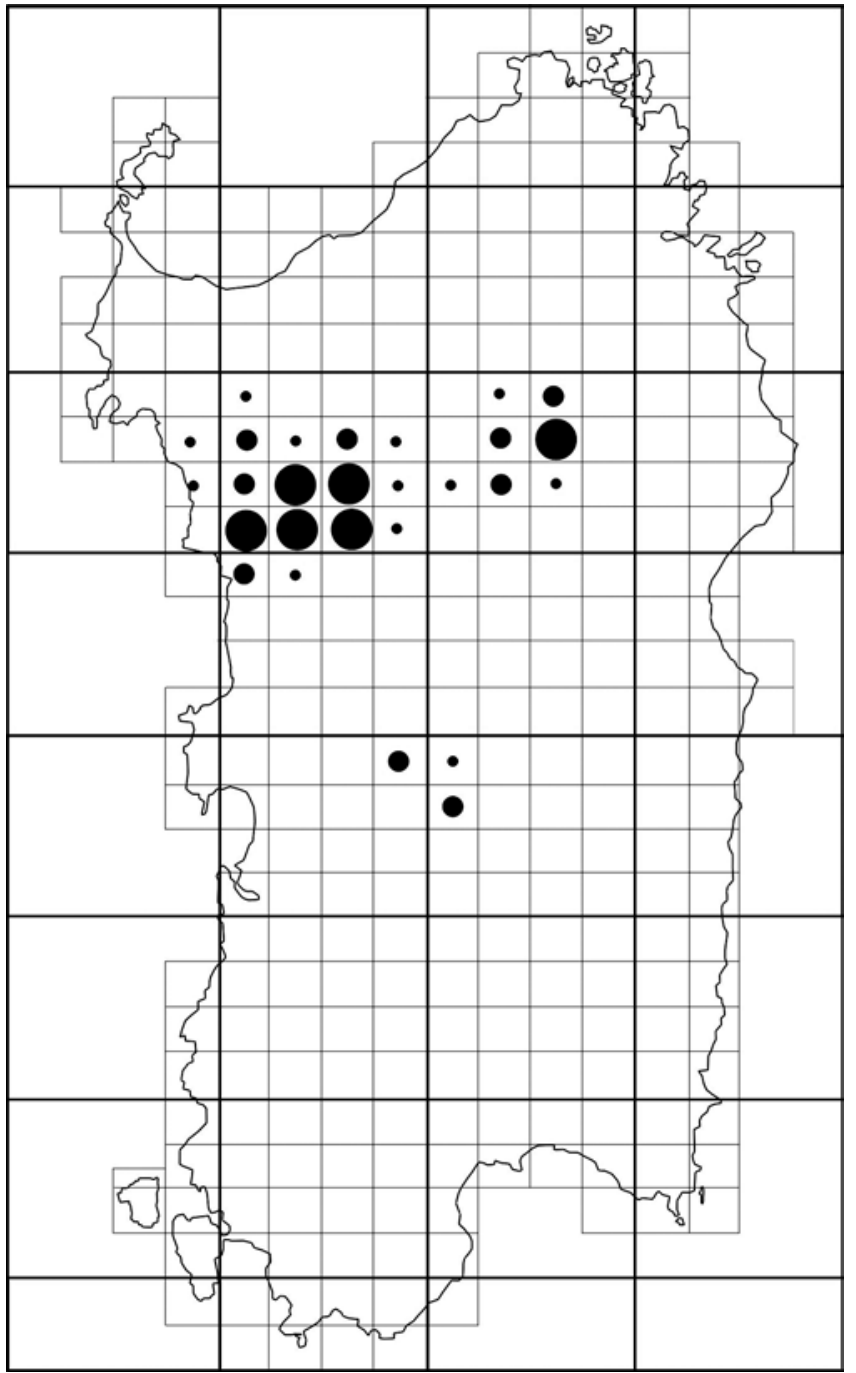

Fig. 4 - Red kite breeding distribution in Sardinia 1985-1994. Large dots indicate confirmed breeding, medium dots indicate probable breeding and small dots indicate possible breeding. / Areale di nidificazione del nibbio reale in Sardegna nel periodo 1985-1994. I pallini grandi indicano una nidificazione certa, quelli medi indicano una nidificazione probabile e quelli piccoli indicano una nidificazione possibile.

significantly lower compared with the breeding population (4 birds in 2012-13, 3 in 2013-14, 12 in 2014-15, 4 in 2015-16) (Grussu in Fulco et al., 2017). Given that great disparity in the last counts carried out by the same author, it is hard to assert that the current estimate shows a real negative trend.

There are no data about a great number of recoveries at the wildlife rescue centre of Bonassai (SS) (Muzzeddu M., ex verbis) and this led us to exclude a negative trend linked to poison events, so it might be possible that there was an overestimate in the latest assess or an error in winter counts.

In the other Mediterranean islands where Red kite is present, the situation is much better given that in Mallorca there are 69 pairs (Muntaner-Yangüela, 2015), in Menorca 27 (De Pablo, 2015) and in Corsica 200-250 (David et al., 2017) whereas in Sicily there is only 1 probably breeding pair in 2018-2020 (Sarà M., pers. comm.). 


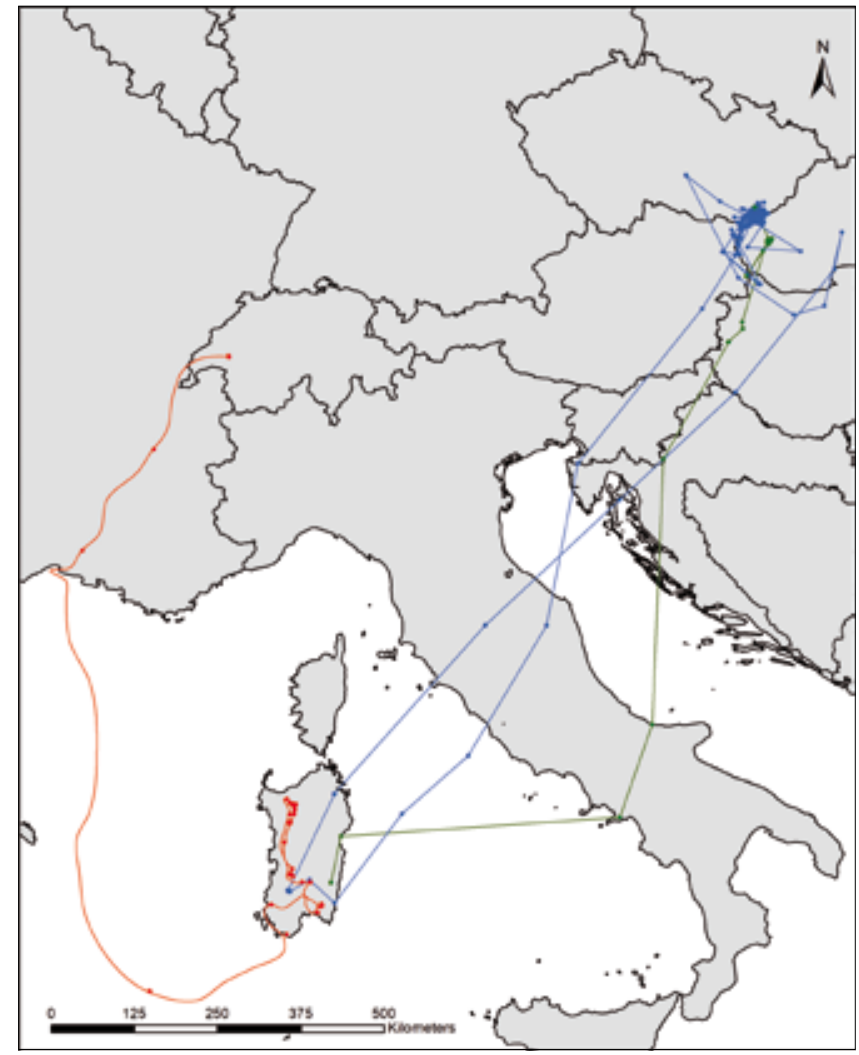

Fig. 5 - Red Kites hatched in the Czech Republic and Switzerland wintering in Sardinia in 2017-18 and 2020-2021. / Nibbi reali nati in Repubblica Ceca e Svizzera svernanti in Sardegna nel 2017-18 e 20202021.

The small Sardinian population is connected with foreign populations, most likely there is a flow of individuals arriving during the winter from nearby Corsica that winter mainly in the north east of Sardinia, but sometimes they could also stay all year round in Sardinia, as demonstrated by the recovery of a dead adult Red kite with a Corsican ring on May $9^{\text {th }} 2002$ that was ringed as chick in 1996 (Grussu et al., 2012).

Recently, thanks to the use of GPS, we acquired much more information and we know that birds from Czech Republic and Switzerland winter in Sardinia. These birds demonstrate that Red kites can easily cross the Adriatic Sea and exceptionally might cross Tyrrhenian Sea to reach Corsica and Sardinia. There is also a ringing data of a German Red kite that was found death during winter in Sardinia (Spina \& Volponi, 2008).

In the next years, in Corsica Red kites will be equipped with GPS (Lepori et al., 2019) and we hope to have more evidence of the connection of the two populations.

In 2018 at the Red kite Symposium in Binaced (Spain) it was very clear for all the researchers present that the Red kite population at the southern edge of distribution range (Sardinia and Sicily, Canary Islands, southern regions of Spain, Black Sea coast in Russia) is starting to suffer problems due to climate change that could be more powerful for the populations that may have lower density and productivity (Cuervo \& Moller, 2013; Maiorano et al., 2013).
Given that the Red kite presence seems to be linked with feeding points, we hope that the positive effects of Life Under Griffon Wings actions might continue, and that, together with the incredible flow of individuals from Corsica observed at the end of December 2020, these factors might increase the number of breeding pairs and contrast climate change effects.

\section{Acknowledgements}

Thanks to Lorenzo De Lisio for editing figures, Ludovic Lepori, Gilles Faggio, Uccio Saccu and Gianluigi Caddeo for informations, Marco Muzzeddu for data from the wildlife rescue centre of Bonassai and the anonymous referee for comments.

\section{REFERENCES}

Aebischer A., 2018 - Population status, distribution changes and conservation problems of the Red kite in Europe. Red kite Symposium in Valsain, Spain.

Berlinguer F., 2020 - Progetto Life Under Griffon Wings LIFE14/NAT/IT/000484 AZIONE D.6 - ECOSYSTEM FUNCTIONS. Università degli Studi di Sassari.

Bezzel E., 1957 - Beiträge zur Kenntnis der Vogelwelt Sardiniens. Anzeiger der Ornithologische Gesellschaft in Bayern, 4: 589-707.

BirdLife International, 2019 - Milvus milvus (amended version of 2018 assessment). The IUCN Red List of Threatened Species: e.T22695072A155600973.

Boitani L., Corsi F., Falcucci A., Maiorano L., Marzetti I., Masi M., Montemaggiori A., Ottaviani D., Reggiani G. \& Rondinini C., 2002 - Rete Ecologica Nazionale. Un approccio alla conservazione dei vertebrati italiani. Università di Roma "La Sapienza”, Dipartimento di Biologia Animale e dell'Uomo; Ministero dell'Ambiente, Direzione per la Conservazione della Natura; Istituto di Ecologia Applicata.

Brooke A. B., 1873 - Notes on the ornithology of Sardinia. Ibis, 3: 334-349.

Cillo N. \& Laterza M., 2014 - Il nibbio reale in Italia. Atti del convegno finale Life Save the flyers "La conservazione del nibbio reale in Europa". Santa Fiora, Grosseto.

Cuervo J. J. \& Møller A. P., 2013 - Temporal variation in population size of European bird species: effects of latitude and marginality of distribution. PLoS One, 8 (10): e77654.

David F., Mionnet A., Riols R. \& Tourret P., 2017 - Plan national d'actions en faveur du Milan royal 20182027. Ministère de la Transition écologique et solidaire.

De Pablo F., 2015 - La gestión de una especie amenazada: historia del milano real en la isla de Menorca en los últimos 22 años. In: In: Llibre verd de protecció d'espècies a les Balears. Valls J. O. $\&$ Ferrà A. A. (eds.). Societat d'Història Natural de les Balears, Palma de Mallorca, Spain: 263274. 
De Rosa D., De Lisio L., Loy A., Senese A., Bucci C. \& Ceccolini G., 2015 - Il Nibbio reale (Milvus milvus) in Molise. Analisi dei monitoraggi ai roost e stima della popolazione nidificante. In: Atti del XVIII Convegno Italiano di Ornitologia, Caramanico Terme (PE), 1720 settembre 2015. De Sanctis A. e Rubolini D. (eds.). Cogecstre Edizioni.

De Rosa D., Fozzi I., Aresu M. \& Caddeo G., 2020 - Red Kite Milvus milvus. In: Bird news. December 2020. Bazzi G. (ed.). Avocetta, 44 (2): 116-117.

Fulco E., Angelini J., Ceccolini G., De Lisio L., De Rosa D., De Sanctis A., Giannotti M., Giglio G., Grussu M., Minganti A., Panella M., Sarà M., Sigismondi A., Urso S. \& Visceglia M, 2017 - Il Nibbio reale Milvus milvus svernante in Italia, sintesi di cinque anni di monitoraggio. Alula, XXIV (1-2): 53-61.

Grussu M., 1995 - Status, distribuzione e popolazione degli uccelli nidificanti in Sardegna (Italia) al 1995. Gli Uccelli d'Italia, 20: 77-85; 21: 5-16.

Grussu M., Medda M. \& Asuni V., 2006 - Status del Nibbio reale e del Nibbio bruno in Sardegna. In: Status e conservazione del Nibbio reale (Milvus milvus) e del Nibbio bruno (Milvus migrans) in Italia e in Europa meridionale. Allavena S. et al. (eds.). Atti del Convegno. Serra San Quirico (Ancona), 11-12 marzo 2006. Parco Naturale Regionale della Gola della Rossa e di Frasassi: 38-39.

Grussu M., Nurchi F., Asuni V. \& Medda M., 2012 - Status e conservazione del Nibbio reale Milvus milvus in Sardegna. Aves Ichnusae, 10: 3-17.

Gustin M., Nardelli R., Brichetti P., Battistoni A., Rondinini C., Teofili C., 2019 - Lista Rossa IUCN degli uccelli nidificanti in Italia 2019. Comitato Italiano IUCN e Ministero dell'Ambiente e della Tutela del Territorio e del Mare, Roma.

Knott J., Newbery P. \& Barov B., 2009 - Action plan for the Red kite Milvus milvus in the European Union. European Commission, Brussels.

Lepori C., 1882 - Contribuzioni allo studio dell'Avifauna Sarda. (Prima parte). Atti della Società italiana di Scienze Naturali, 25 (3): 293-345.

Lepori L., Cart S., Lebret A. \& Linossier J., 2019 - Plan national d'actions du Milan royal en Corse - 2019. CEN Corse, DREAL Corse, OEC.

Maiorano L., Cheddadi R., Zimmermann N. E., Pellissier L., Petitpierre B., Pottier J. \& Singarayer J. S., 2013 Building the niche through time: using 13,000 years of data to predict the effects of climate change on three tree species in Europe. Global Ecology and Biogeography, 22 (3): 302-317.

Massa B. \& Schenk H., 1983 - Similarità tra le avifaune della Sicilia, Sardegna e Corsica. Lavori della Società italiana di Biogeografia, VIII (1980): 757-799.

Muntaner-Yangüela J., 2015 - Evolució poblacional del voltor negre (Aegypius monachus), voltor lleonat (Gyps fulvus) i milà (Milvus milvus) a les Illes Balears fins 2014. In: Llibre verd de protecció d'espècies a les Balears. Valls J. O. \& Ferrà A. A. (eds.). Societat d'Història Natural de les Balears: 275-282.

Salvadori T., 1864 - Catalogo degli uccelli di Sardegna. Tipografia Bernardoni, Milano.
Schenk H., 1976 - Analisi della situazione faunistica in Sardegna. Uccelli e mammiferi. In: S.O.S. Fauna, Animali in pericolo in Italia. Savini Mercuri, Camerino: 465-556.

Schenk H., 1995 - Status faunistico e di conservazione dei vertebrati riproducentisi in Sardegna, 1990-93: contributo preliminare. In: Studio, gestione e conservazione della fauna selvatica in Sardegna. Cossu S. et al. (eds.). Edizioni del Sole, Amministrazione Provinciale di Oristano: 41-71.

Schenk H., 2015 - Lista Rossa dei Vertebrati che si riproducono in Sardegna (Amphibia, Reptilia, Aves, Mammalia) 2000-2009. In: Una vita per la Natura. Omaggio a Helmar Schenk. Aresu M., Fozzi A. \& Massa B. (eds.). L'Unione Sarda, Cagliari: 127-220.

Spina F. \& Volponi S., 2008 - Atlante della Migrazione degli Uccelli in Italia. 1. Non-Passeriformi. Ministero dell'Ambiente e della Tutela del Territorio e del Mare, Istituto Superiore per la Protezione e la Ricerca Ambientale (ISPRA). 